\title{
Paxil: part of the process
}

A patent that claims a product made by a new process can be anticipated by prior art that discloses the product being made, according to a ruling on a recent case between GlaxoSmithKline (GSK) and generics manufacturers Apotex. The lawsuit concerns the validity of a product-by-process patent (USP 6,113,944) for paroxetine (Paxil; GSK), which was called into question when GSK sued Apotex for infringement. Apotex argued that the ' 944 patent is invalid because it is anticipated by an earlier product patent for paroxetine, which was filed in 1986 (USP 4,721,723).

The original purpose of the product-by-process claim is to enable inventors to "claim an otherwise patentable product that resists definition other than the process by which it is made". However, product-by-process claims are now often used even if the invention could be fully described independently of the process by which it was made. Therefore, the courts had to focus on two issues: whether the scope of the ' 944 patent is broad enough to claim paroxetine made by any process; and whether the earlier' 723 patent contains any limitation as to the process by which paroxetine is made.

The district court determined that it is undisputed that the product of the ' 944 patent is paroxetine and that despite GSK's attempts to argue that the form of paroxetine in the ' 944 patent had slightly different characteristics (lacking a pink hue and spherical granules and having different content uniformity), these characteristics were not required by the ' 944 patent claims or specification. As such, the court concluded that anticipation by the earlier disclosure of paroxetine could not be avoided by claiming the product more narrowly in the later' 944 patent, and that therefore the ' 723 patent anticipates the ' 944 patent by claiming paroxetine "without regard to the process by which it was made".

On appeal, the US Court of Appeals for the Federal Circuit (CAFC) upheld the lower court's ruling, stating that GSK did not establish that the district court erred in its judgement. When considering GSK's argument that the product produced by the process claimed in the ' 944 patent was different to that disclosed in the ' 723 patent, the CAFC waived this issue for failure of GSK to brief it on appeal. The ' 944 patent is therefore invalid and unenforceable and the CAFC upheld the award of summary judgement to Apotex.

SmithKline Beecham and GlaxoSmithKline v. Apotex Corp. and Torpharm, No. 04-1522 (24 Feb 2006): http://www.fedcir.gov/opinions/04-1522.pdf

Joanna Owens

\section{Friends in high places}

A recent ruling by the US Court of Appeals for the Federal Circuit (CAFC) in a case of inequitable conduct provides a cautionary tale about disclosing conflicts of interest when making or including expert 'declarations' during patent lawsuits.

The case came to the Appeals court after Ferring and Aventis sued Barr Laboratories for infringement of USP 5,407,398, which claims a solid oral dosage of a peptide antidiuretic drug, 1-deamino-8-D-arginine vasopressin, for absorption in the gastrointestinal tract of humans. Barr had argued that the '398 patent is unenforceable as a result of inequitable conduct because several key declarations made during the initial patent examination and thereafter were written by scientists who had significant links to Ferring. The recent ruling of the Appeals Court affirmed the lower court's ruling of inequitable conduct and finds the ' 398 patent unenforceable.

Ferring was found guilty of inequitable conduct and intent to mislead patent examiners because it knowingly included affidavits from interested parties without disclosing the links between the parties and the company. During the application process for the '398 patent, examiners were concerned about a prior art reference, US patent 3,497,491, which claimed that "1-deamino-8-Darginine vasopressin... may be used for the parenteral, peroral, intranasal, subcutaneous, intramuscular, or intravenous application." It is the use of the term 'peroral' that is at issue. The examiners were concerned that peroral suggests the oral administration of the peptide for gastrointestinal absorption and requested that the applicants obtained evidence from a non-inventor to support their conflicting interpretation of the term.

The inventors provided four declarations stating that peroral should be interpreted as "administration of a drug through the mouth but only for absorption through the cheek or under the tongue" but this did not convince patent examiners, and a protracted episode of patent rejection and re-examination ensued, ultimately culminating in a new round of examination in which the inventors submitted declarations from three of the original experts plus two additional new declarations.

The '398 patent was eventually issued in September 1991, and Ferring exclusively licensed the right to market and sell the antidiuretic compound to Aventis. But when Barr filed its Paragraph IV certificate claiming invalidity of the '398 patent, it came to light that four of the five declarations submitted to the Patent and Trademark Office (PTO) were written by scientists who had been employed or had received research funds from Ferring, and that one of the key inventors for Ferring had participated in the drafting of two of the four declarations. Given the initial reluctance of the PTO to issue the '398 patent and the fact that when it eventually did so it relied crucially on the expert declarations as material evidence, both the District and Appeals courts ruled that Ferring intended to mislead the PTO and was guilty of inequitable conduct.

The summary of the CAFC acknowledged that when an inventor is asked to provide supportive declarations it might be completely appropriate for this to come from a colleague or someone who has been affiliated with the inventor at some point, but cautioned that when a non-inventor declaration is specifically requested, and when the objectivity of such declarations is of paramount importance to the patent being issued, the inventor must disclose any known relationships and affiliations of the declarants so that they can be taken into consideration by the patent examiner.

Ferring and Aventis v. Barr Labs, No. 05-1284 (15 Feb 2006): http://www.fedcir.gov/opinions/05-1284.pdf

\section{Joanna Owens}

PATENT ADVISORS

Leslie Meyer-Leon: IP Legal Strategies Group, Cape Cod, MA, USA

Philip Webber: Frank B. Dehn \& Co. London, UK George W Schlich: Schlich \& Co, London

Daniel M Becker: Heller Ehrman, Menlo Park, CA, USA 